\title{
GEOLOGIC SECTION OF THE UPDIP COASTAL PLAIN FROM CENTRAL GEORGIA TO WESTERN SOUTH CAROLINA
}

\author{
By
}

\author{
David C. Prowell, Raymond A. Christopher, Luey E. Edwards, \\ Laurel M. Bybell, and Harold E. Gill
}

\section{INTRODUCTION}

Stratigraphic investigations of the Atlantic and Gulf Coastal Plains of the southeastern United States have shown that the two regions contain distinctly different Cretaceous and Tertiary sedimentary rock sequences. These two regions merge in Georgia where the Southwest Georgia Embayment, representing the eastern end of the Gulf Coast strata, meets the Southeast Georgia Embayment, representing the southern end of the Atlantic Coast strata. The correlation of strata between these two regions has been the subject of longstanding controversy among Coastal Plain stratigraphers, paleontologists, and hydrologists. New drill-hole data and stratigraphic interpretations presented in this report provide additional lines of correlation between the Atlantic and Gulf sections.

As a part of a hydrologic study in central and eastern Georgia during 1981-84, the U.S. Geological Survey, in cooperation with the Georgia Geologic Survey, drilled four, discontinuously cored, hydrologic test wells in the updip Coastal Plain along a line approximating the strike of the Fall Line (index map). Other partly cored wells had been drilled previously in easternmost Georgia and adjacent South Carolina during geologic investigations for the siting of nuclear facilities in the area (Marine and Siple, 1974; Bechtel Corporation, 1982). Data from three separate wells (Arrowhead 1, Wrightsville 1, and Midville SEX-TW-2) and from two clusters of wells (Laurens 1, 2, and 3; SRP-P5R and Vogtle VSC-2) were used to construct a detailed geologic section from central Georgia to western South Carolina. In the cluster wells the best samples were used to describe the lithologic characteristics of the geologic units in the area. Laurens 1,2 , and 3 are adjacent wells at the same locality; and well VSC-2 is approximately $1 \mathrm{mi}$ southeast of well SRP-P5R. Information concerning the location and depths of these wells is shown in table 1 .

Descriptions of the rock units shown on the geologic section are given in this pamphlet. Geophysical logs are included on the geologic section because of their usefulness in defining unit contacts in the intervals of no core recovery. Analyses of pollen, dinoflagellates, and calcareous nannofossils in selected samples were made to determine the age of rock units and to provide evidence of paleoenvironmental conditions. The drill hole at the west end of the section line (Arrowhead 1) contains strata correlative with the Gulf Coastal Plain formations in the Southwest Georgia Embayment, whereas the drill-hole locality at the east end (wells SRP-P5R and VSC-2) contains lithologies characteristic of the Atlantic Coastal Plain sequence.

The geologic units shown on the section are labeled only with symbols to avoid possible confusion between Gulf and Atlantic formation nomenclature and the stratigraphic implications connected with existing formation names. Formations of equivalent age are given at the end of each unit description and in the correlation chart (table 2). Diagnostic fossils are listed individually and their age significance is commonly given in terms of biologic zonation. For additional information concerning the ranges of dinoflagellates, refer to the articles by Drugg and Stover (1975) and Edwards (1980). A definition of the Paleogene calcareous nannoplankton (NP) zones can be found in Martini (1971), and a descrirtion of Cretaceous pollen zonations is included in Christopher (1978), Christopher (1982), Sohl and Christopher (1983), and Wolfe (1976).

Key aspects of the geologic section are: (1) the total absence of any pre-Santonian Cretaceo's strata (for example, the Tuscaloosa Formation), (2) the gradual thinning and ultimate omission of some Cretaceous units from west to east, (3) a general transition in Cretaceous strata from marine deposits in the west to terrestrial deposits farther east, (4) the thinning of Tertiary strata from the centen of the geologic section to the east and west, and (5) the low radioactivity levels (note gamma logs) of Eo?ene and younger strata. The low radioactivity of there strata when compared to the older Tertiary and Crataceous strata implies a major change in provenance following the Paleocene Epoch. The gamma log signature represents a useful tool for defining the Paleocene/Eocene boundary in the study area.

\section{ACKNOWLEDGMENTS}

The authors acknowledge the assistance of Wendell Marine of E.I. du Pont de Nemours Co., the Savannah River Plant authorities, the Georg' 9 Power Co., the Georgia Geologic Survey, and t? South Carolina Geological Survey. We also appreciate the suggestions by Gregory S. Gohn, Juergen Reinhardt, 
James P. Owens, and Willis Hester of the U.S. Geological Survey.

\section{DESCRIPTION OF GEOLOGIC UNITS Unit $\mathbf{M}_{1}$}

This unit is composed of fine to coarse, poorly sorted sand in a heavily stained clay matrix. The sand is predominantly subangular quartz containing minor amounts of dark heavy minerals and mica. The clay matrix ranges from off-white to yellow-orange to red; this variegated color is probably caused by subaerial weathering and oxidation at the present land surface. A layer of grit and fine gravel marks the basal contact, but gravel layers within the unit are rare. No traces of calcium carbonate, silicification, or megafossils were recognized in any of the samples.

No biostratigraphic data were obtained from unit $M_{1}$, but its position above units $E_{8}$ and $O_{1}$ suggests that it is post-Eocene and probably postOligocene in age. Accordingly, we have assigned a Miocene age to this unit. Although stratigraphic correlation of unit $\mathrm{M}_{1}$ with other geologic units is tenuous, unit $M_{1}$ is most likely an updip lithofacies of the Hawthorn Formation of eastern Georgia and western South Carolina (table 2).

\section{Unit $o_{1}$}

This unit is composed of clay and fine to medium, well-sorted sand containing thin chert lenses and nodules. The sand is largely subangular to subrounded quartz, but also contains mica and fine dark heavy minerals. The base of the unit consists of thinly interbedded sand and clay, whereas the upper part of the unit is massive to poorly bedded and contains red staining suggestive of subaerial weathering. Some sand layers have a brown to orange clay matrix. Some chert fragments contain megafossil impressions, which suggests that the chert layers may be silicified limestone beds.

No diagnostic fossils have been recovered from unit $O_{1}$. Its position atop beds of latest Eocene age (unit $E_{8}$ ) suggests that it is probably Oligocene, but it may be younger. The well-sorted sand, the thinly bedded clay and sand at the base, and the fossiliferous chert layers suggest that $O_{1}$ strata were deposited in a shallow, nearshore marine environment.

The probable biostratigraphic equivalent of unit $\mathrm{O}_{1}$ in South Carolina (table 2) is the upper part of the Cooper Formation (Hazel and others, 1977). In eastern Georgia and adjacent South Carolina, the biostratigraphic and lithologic equivalent of unit $\mathrm{O}_{1}$ could be the Tobacco Road Sand Member of the Barnwell Formation. Although the Tobacco Road Sand Member is considered late Eocene (Jacksonian) by Huddlestun and Hetrick (1979), Nystrom and Willoughby (1982) and Prowell and O'Connor (1978) present evidence that it could be Oligocene.

\section{Unit $E_{8}$}

This unit is divided into two subunits, $E_{8 g}$ and $E_{8 b}$, to include a lithofacies recognized only in the Midville test well. Biostratigraphic evidence presented below suggests that these subunits are ageequivalent lithofacies; therefore, they are classified under the same unit heading.

Subunit $E_{8 a}$ is a fine to medium clayey sand containing thin beds of impure limestone, thin clay layers, and beds of well-rounded gravel. The sand is largely well-sorted, subangular to subrounded quartz, but small amounts of mica, fine dark heavy minerals, and white kaolin fragments also are present. The clayey matrix, largely kaolinite with some illite/smectite, is typically buff, orange, or red. Some sand layers have a weak calcareous cement, but these are generally in the lower part of the subunit. The base of subunit $E_{8}$ in eastern Georgia and South Carolina is marked by very coarse grit and fine gravel, whereas west of the Midville test well the base contains thin fossiliferous limestone beds.

In the Midville test well, a thick sequence of green-to-gray marl (subunit $E_{8 b}$ ) occupies the same stratigraphic position as subunit $\mathrm{E}_{8 \mathrm{~g}}$ in the other wells. The cuttings obtained from the marl suggest that it is a fairly uniform mixture of fine sand, clay, aild calcium carbonate containing minor amounts of glauconite and fine dark heavy minerals. The geophysical logs for the Midville test well suggest that the marl is massive to uniformly bedded and that it contains some phosphate layers near the top. Some shell fragments were observed in the cuttings, but the bulk percentage of shell material in the subunit is unknown.

Microfossils collected from the carbonate layers in subunit $E_{8 g}$ and from the marl at the top of subunit $E_{8 b}$ are largely dinoflagellates and calcareous nannofossils. Preservation is only fair, and many taxa are represented by only a few specimens per sample. Pollen is never more than a minor constituent. The identified calcareous nannofossils include Isthmolithus recurvus Deflandre, Discoaster barbadiensis Tan Sin Hok, and Cyclococcolithus reticulatus Gartner \& Smith, which indicate a late Eocene (Jacksonian) age (Zones NP 19/20). Diagnostic dinoflagellates found in unit $\mathrm{E}_{8}$ include Adnatosphaeridium sp., Areosphaeridium dictyostilum (Menéndez) Sarjeant, Batiacasphaera compta Drugg, Deflandrea cf. $D$. heterophlycta Deflandre \& Cookson, Homotryblium floripes (Deflandre \& Cookson) Stover, Kisselovia coleothrypta (Williams \& Downie) Lentin \& Williams, Membranophoridium aspinatum Gerlach, Pentadinium laticinctum Gerlach, Samlandia chlamydophora Eisenack, and Spiniferites spp. In addition, a single specimen of Cordosphaeridium funiculatum Morgenroth was found at Midville (100-110 ft), and Distatodinium virgatum Stover and Phthanoperidinium comatum (Morgenroth) Eisenack \& Kjellström were found at Wrightsville (191 ft). The well-sorted sand and associated rounded gravels, the limestone beds, and the abundant microfossils suggest that subunit $E_{8}$ was deposited in a nearshore marine environment, probably as part of a shallow shelf-barrier complex. The massive nature of subunit $E_{8 b}$ suggests that it accumulated in deeper water, perhaps in a more openshelf environment.

The biostratigraphic equivalent of unit $E_{8}$ in western Georgia and eastern Alabama is the Ocala Limestone, whereas in western Alabama it is the Yazoo Clay (table 2). In central and eastern Georgia, the biostratigraphic and lithostratigraphic equivalents of subunit $\mathrm{E}_{8 \mathrm{a}}$ are the Irwinton Sand Member and the Tobacco Road Sand Member(?) of the Barnwell Formation (Huddlestun and Hetrick, 1979). The equivalent of subunit $E_{8 b}$ is the lower part of the Cooper Formation of western South Carolina (Gohn and others, 1977). 


\section{Unit $E_{7}$}

Unit $E_{7}$ is a dark-gray to green carbonaceous clay to marl containing beds of silt, fine sand, and limestone. Glauconite, phosphate, mica, and fine dark heavy minerals are secondary components. Silicacemented nodules are locally present in unit $E_{7}$ but they are of uncertain origin. The lower part of the unit is generally massive, whereas the upper part is well bedded and typically thinly laminated. Cores from this unit have a hackly fracture that is commonly characteristic of a high montmorillonite content. Macrofossiliferous limestone beds occur throughout the sequence and the matrix contains abundant microfossils.

Samples from unit $E_{7}$ contain a variety of microfossils. Diagnostic calcareous nannofossils include Isthmolithus recurvus Deflandre, Cyclococcolithus reticulatus Gartner \& Smith, Discoaster barbadiensis Tan Sin Hok, and Discoaster saipanensis Bramlette \& Riedel, which are indicative of a late Eocene (Jacksonian) age (Zone NP 19/20). Characteristic dinoflagellates from this unit are Batiacasphaera baculata Drugg, Batiacasphaera compta Drugg, Cordosphaeridium funiculatum Morgenroth, Kisselovia coleothrypta (Williams \& Downie) Lentin \& Williams, Millioudodinium sp., Palaeocystodinium golzowense Alberti, Pentadinium laticinctum Gerlach, Rhombodinium draco Gocht, and Samlandia chlamydophora Eisenack. In addition, Membranophoridium aspinatum Gerlach was found in the Arrowhead well at a depth of $102 \mathrm{ft}$. Preservation is fair and diversity is low, but these species indicate a late Eocene to early Oligocene age. The abundance of marine microfossils in this unit, the beds of limestone, and the thinly laminated clay to marl suggest that this unit was deposited in a marine shallow-shelf environment.

The lithologic and biostratigraphic equivalent of unit $\mathrm{E}_{7}$ in eastern Georgia (table 2) is the Twiggs Clay Member of the Barnwell Formation (Huddlestun and Hetrick, 1979). In western Georgia, the biostratigraphic equivalent is the Ocala Limestone, and in coastal South Carolina it is the lower part of the Cooper Formation (Gohn and others, 1977; Hazel and others, 1977).

\section{Unit $\mathbf{E}_{6}$}

This unit is a well-sorted calcareous quartz sand containing beds of silty to sandy marl and layers of bivalve shells and shell fragments. The sand is fine to medium, subrounded to rounded, clear quartz enclosed in a matrix of buff to gray calcium carbonate. The base of this unit is characteristically marked by a 5foot-thick zone of coarse calcareous sand containing numerous bivalve shells and other macrofossils. Above this basal layer, unit $\mathrm{E}_{6}$ consists of very calcareous sand to sandy limestone and less-common sandy marl. The upper part of the unit is less calcareous fine sand with local limestone and shell layers.

Megafossils and microfossils are present throughout the entire $E_{6}$ sequence. The moderately diverse, well-preserved dinoflagellate flora includes Adnatosphaeridium sp., Corrudinium incompositum (Drugg) Stover \& Evitt, Cyclopsiella vieta Drugg \& Loeblich, Homotryblium floripes (Deflandre \& Cookson) Stover, Hystrichokolpoma rigaudiae
Deflandre \& Cookson, Kisselovia coleothrypta (Williams \& Downie) Lentin \& Williams, Palaeocystodinium golzowense Alberti, Pentadinium laticinctum Gerlach, Phthanoperidinium comatum (Morgenroth) Eisenack \& Kjellström, Samlandia chlamydophora Eisenack, Selenopemphiv nephroides Benedek, Spiniferites pseudofurcatur (Klumpp) Sarjeant, and Systematophora placacanthx (Deflandre \& Cookson) Davey et al. In addition, Areosphaeridium dictyostilum (Menéndez) Sarjeant, Apteodinium australiense (Deflandre \& Cookson) Williams, and Cordosphaeridium cantharellum (Brosius) Gocht, Corrudinium sp., Dapsilidinium pseudocolligerum (Stover) Bujak et al., Lingulodinium machaerophorum (Deflandre \& Cookson) Wall, and Rhombovinium draco Gocht are present in the Laurens-1 well. These species, combined with those of overlying units, suggest unit $E_{6}$ is early late Eocene (Jacksonian). Unit $\mathrm{E}_{6}$ marks the beginning of the upper Eocene stage in this region. The abundance of megafossils and microfossils in unit $E_{6}$, and the calcium carbonate matrix and limestone beds, indicate the strata were deposited in an open-marine environrient. The calcareous sand probably was deposited in a shallowshelf environment, and the fossil bed at the base is a lag deposit from the late Eocene marine transgression. The biostratigraphic and lithologic equivalent of unit $E_{6}$ in central and eastern Georgia (table 2) is the Clinchfield Sand Member of the Barnwell Formation (Huddlestun and Hetrick, 1979). This unit also is the biostratigraphic equivalent of the Moodys Branch Formation in western Georgia (Hazel and others, 1977).

\section{Unit $\quad E_{5}$}

This unit is a massive, fine to medium, very clayey, calcareous quartz sand containing thin beds of fossiliferous limestone and dark gray-to-green clay. The sand is typically well-sorted, subro'inded, clear quartz in a calcareous clay matrix. Traces of glauconite, phosphate, and mica have been noted in some samples. Impure limestone occurs in thin beds throughout the unit, and limestone nodules are locally present in the upper part of the unit. Numerous megafossils are concentrated in layers adjacent to some of the limestone beds, and the clay matrix is very microfossiliferous.

In this unit, the floras have lo'v diversity, preservation is only fair, and pollen is n?t abundant. Calcareous nannofossil samples are charicterized by Helicosphaera compacta Bramlette \& Wilcoxon, Cyclococcolithus reticulatus Gartner \& Smith, Pemma papillatum Martini, Dictyococcites bisectus (Hay et al.) Bukry \& Percival, and Discoaster bark rdiensis Tan Sin Hok, which indicate that unit $E_{5}$ is late middle Eocene (Zone NP 16/17). Diagnostic dinoflagellates include Pentadinium goniferum Edwards, Pentadinium polypodum Edwards, Cordosphaeridium gracile (Eisenack) Davey \& Williams, Membranorhoridium cf. $M$. aspinatum Gerlach and Thalassiphora pelagica (Eisenack) Eisenack \& Gocht. In addition, Areosphaeridium dictyostilum (Menéndez) Sarjeant and Rhombodinium glabrum (Cookson) Vozzhennikova are present in the Arrowhead well at $189 \mathrm{ft}$. This flora is indicative of the upper half of the middle Eocene (late Claibornian) stage in the Gulf Coastal Plain. The massive bedding in the calcareous sard, the thin limestone beds, the shell-hash zoner, and the 
abundance of marine microfossils suggest that the $E_{5}$ strata were deposited in an open-marine, shallow-shelf environment.

The biostratigraphic and lithostratigraphic equivalent of unit $E_{5}$ in western Georgia is the Lisbon Formation (table 2). The equivalent unit in eastern Georgia and western South Carolina is the Lisbon Formation and (or) the McBean Formation. In eastern South Carolina, the biostratigraphic equivalent is the Santee Limestone, but the two units have somewhat different lithologies.

\section{Unit $\mathbf{E}_{\mathbf{4}}$}

This unit is composed primarily of fine to medium, clayey to slightly calcareous sand in central Georgia, whereas it is very calcareous sand and sandy limestone in South Carolina. Accordingly unit $\mathrm{E}_{4}$ is divided into two subunits, $E_{4 a}$ and $E_{4 b}$, to reflect the clastic-to-carbonate change in lithofacies in eastern Georgia. The sand unit $\mathrm{E}_{4 \mathrm{a}}$ typically is well-sorted, clear to smoky quartz, and some grains are well polished. The majority of the sand is fine grained, but a thin layer of coarse subangular sand may be present at the basal unconformity. Mica and dark heavy minerals are abundant in some sand layers, and lignite fragments are present in the coarser intervals. Thin clay layers are prominent in the Arrowhead and Laurens-1 cores, and the clays are well-laminated to massive and commonly highly carbonaceous, with a diverse marine microflora. Cuttings from the Wrightsville and Midville wells suggest that subunit $\mathrm{E}_{4 \mathrm{a}}$ contains layers of fossiliferous marl and very calcareous sand, but limestone is not present.

The cores from well VSC-2 and cuttings from well SRP-P5R indicate that subunit $E_{4 b}$ is largely a highly calcareous sand, grading to sandy, shelly limestone in the lower third of the section, with a very sandy limestone at the base. The calcareous sand is mostly clear, rounded to subrounded quartz, containing minor amounts of glauconite or phosphate. The carbonate cement typically is light gray and fine grained. The sandy limestone typically is very porous, is light-gray, and contains various quantities of megafossils or fossil molds and casts.

Samples taken from unit $\mathrm{E}_{4}$ have a diverse microflora with fair preservation. Dinoflagellates from the lower part of the unit include a new species of Eocladopyxis, Muratodinium fimbriatum (Cookson \& Eisenack) Drugg, Pentadinium favatum Edwards, Pentadinium goniferum Edwards, and Polysphaeridium zoharyi (Rossignol) Bujak et al. Samples from the upper part of the unit contain Kisselovia coleothrypta (Williams \& Downie) Lentin \& Williams, Muratodinium fimbriatum (Cookson \& Eisenack) Drugg, Pentadinium goniferum Edwards, "Rhombodinium draco" of Drugg and Stover (1975), Samlandia reticulifera Cookson \& Eisenack, and Thalassiphora pelagica (Eisenack) Eisenack \& Gocht. In addition, Lentinia spp., Spiniferites spp., and Wetzeliella spp. are present in many samples. These species establish the age of unit $\mathrm{E}_{4}$ as lower-middle to middle-middle Eocene (middle Claibornian). The abundance of marine microfossils, layers containing megafossils, calcareous beds, and well-sorted-sand beds suggest that subunit $E_{4 b}$ was deposited in a nearshore, sediment-starved, marine environment. The less-calcareous nature of subunit $\mathrm{E}_{4 \mathrm{a}}$ to the west suggests that it may be part of a barrier-dominated coastline, perhaps under deltaic influence as implied by the carbonaceous debris and massive clay deposits.

The biostratigraphic equivalent of unit $E_{4}$ in western Georgia and Alabama is the lower half of the Lisbon Formation (table 2). The calcareous strata $\left(E_{4 b}\right)$ in the VSC-2 well may be correlative with parts of the Warley Hill Marl and (or) Congaree Formation of South Carolina (Pooser, 1965), the Moultrie Member of the Santee Limestone (Ward and others 1979), and possibly the upper part of the Huber Formation (Buie, 1978) of eastern Georgia. The noncalcaresus parts of unit $E_{4}$ are lithologically similar to strata of the Huber Formation, whereas the calcareous parts resemble the lithofacies in the Lisbon Formation.

\section{Unit $\mathbf{E}_{\mathbf{3}}$}

This unit is composed of fine to coarse, moderately sorted, slightly clayey sand containing a few thin beds of clay or silty clay. The sand is mostly clear or smoky quartz and is generally subrounded. Well-rounded quartz gravel locally is present in thin beds near the base of the unit. The unit also contains a moderate amount of fine to coarse muscovite, a variety of dark heavy minerals, lignite, ard traces of glauconite. The matrix clays tend to be olive-green to gray, depending on the concentration of disseminated carbon, and the color of the sand ranges from white to gray to light olive, depending on the clay matrix. Clay-lined burrows are present in the sandier beds, and inclined bedding in the cored intervals s'lggests the presence of cross bedding. Discrete clay layers are uncommon, and those present are only a few feet thick and generally highly carbonaceous. $l^{\top} 0$ calcium carbonate or megafossils have been recognized anywhere in the unit. In the Arrowhead well, the top of unit $E_{3}$ is cemented and is stained brigh $t$ red. This would suggest the possibility of subaerial weathering prior to the deposition of unit $\mathrm{E}_{4}$.

The few carbonaceous clay layers in unit $E_{3}$ are characterized by a microflora of low diversity. Preservation is only fair, but some diagnostic dinoflagellates have been identified. The important species are Achilleodinium biformoides (Eisenack) Eaton, "Lanternosphaeridium lanosum" of Drugg and Stover (1975), Pentadinium favatum Ecwards, and Wetzeliella/Gochtodinium. These spocies are indicative of an early middle Eocone (early Claibornian) age. The presence of a marine microflora, the clay-lined burrows, and predominance of sand in the unit suggests that deposition was in a very nearshore, marine environment. The presence of lignite and carbonaceous debris throughout the unit suggests that unit $E_{3}$ may have been part of a deltaic complex.

The biostratigraphic equivalent of unit $E_{3}$ in Alabama is the upper part of the Tallahatta Formation (table 2). In eastern Georgia, the biostratigraphic equivalent is the upper part of the Huber Formation. Unit $E_{3}$ is lithologically similar to the updip part of the Tallahatta Formation of western Georgia and eastern Alabama and to the sandy phases of the upper half of the Huber Formation of central and eastern Georgia.

\section{Unit $\quad \mathbf{E}_{\mathbf{2}}$}

This unit is composed of fine to vary coarse, subrounded to subangular, moderately sorted sand 
containing a minor amount of white clay matrix. The sand is mostly clear to smoky quartz and includes some muscovite and sparse dark heavy minerals. Large lignite fragments are common in the coarser intervals, and one very thin carbonaceous clay layer is present at the base of the sequence. Unit $E_{2}$ is present only in the Arrowhead well, and core recovery in this interval was poor. Unit $E_{2}$ is very similar to unit $E_{3}$, but a red to orange staining at the top of $E_{2}$, and the distinct microflora of the carbonaceous clay layer, imply that it is a separate stratigraphic unit of limited extent.

Preservation of microflora in unit $E_{2}$ is very poor, and many specimens are fragmented. Characteristic dinoflagellates that have been identified are Cordosphaeridium gracile (Eisenack) Davey \& Williams, Kisselovia coleothrypta (Williams \& Downie) Lentin \& Williams, and Wetzeliella varielongituda Williams \& Downie. The presence of $K$. coleothrypta and the microflora assemblage of overlying unit $E_{3}$ suggests that the $E_{2}$ strata were deposited in the early Eocene, but $E_{2}$ clearly is not the oldest lower Eocene unit in the stratigraphic section. The relatively well-sorted quartz sand, lignite fragments, carbonaceous clay, and marine microflora suggest that unit $E_{2}$ probably is a proximal marine deposit associated with deltaic deposition.

This unit probably is the biostratigraphic equivalent of the middle lower Eocene "Tallahatta" Formation of Hazel and others (1984) and the lower Eocene part of the Tallahatta Formation as defined by Bybell and Gibson (1985) in Alabama, which is lithologically continuous with the middle Eocene Tallahatta Formation (table 2). The lithologic similarity of unit $E_{2}$ to unit $E_{3}$ in the Arrowhead test well supports the observation of Hazel and others (1984) and Bybell and Gibson (1985) regarding redefinition of the Tallahat ta strata.

\section{Unit $\mathbf{E}_{1}$}

This unit is composed of thick sequences of well-laminated to massive clay containing thinner beds of moderately to well-sorted quartz sand. The clay layers in this unit are largely silty to sandy kaolin and contain various amounts of carbonaceous material. The clay beds with no carbonaceous material appear massive and are generally off-white to buff. The presence of carbonaceous material gives the clay beds a well-laminated appearance, highlighting subtle textural differences. The amount of carbonaceous material in unit $E_{1}$ is greatest in the Arrowhead well and diminishes to the east. Cores from well VSC-2 contain only minor amounts of finely disseminated carbon, giving the clays a pale-gray color. The sand beds in unit $\mathrm{E}_{1}$ are generally fine to medium grained, although layers of coarse sand and gravel may be present. The sand is largely subangular quartz containing large amounts of muscovite and minor dark heavy minerals. Large lignite fragments are common, and inclined layers suggest the presence of crossbedding.

The diversity of microflora in unit $E_{1}$ is low, but preservation is fair. Diagnostic dinoflagellates include "Eocladopyxis peniculata" of Williams and Brideaux (1975), Hafniasphaera goodmanii Edwards, Wetzeliella sp., Wilsonidium tabulatum (Wilson) Lentin \& Williams, and Wetzeliella ef. W. hampdenensis Wilson. These species suggest that unit $E_{1}$ is of early Eocene age and slightly older than unit $E_{2}$. The massive clays, the abundance of carbonaceous material, and a marine microflora suggest th॰t unit $E_{1}$ was deposited in a proximal marine environment, probably as part of a large delta complex.

Unit $E_{1}$ is the biostratigraphic equivalent of the Bashi Formation (formerly Bashi Member of the Hatchetigbee Formation of Alabama) and passibly of the Fishburne Formation of eastern South Carolina (table 2). The clayey parts of the unit are lithologically similar to the clayey parts of the Bashi Formation except that the Bashi tend: to be calcareous, whereas $E_{1}$ strata are not.

\section{Unit $\mathbf{P}_{\mathbf{2}}$}

This unit is composed of fairly dense, silty to sandy kaolin containing some mica, fine dark heavy minerals, and minor amounts of cart mnaceous material. The kaolin is largely off-white to buff, with pale red and orange streaks in most of the unit. Coarse sand in a clay matrix may be present at the base of $\mathrm{P}_{2}$, but the unit is otherwise largely clay in western areas and becomes much siltier to the east. The sand in the section is fine to coarse ard largely angular. Finely disseminated carbon is pesent in many areas, as evidenced by the pale gray color in some intervals. Only in the Arrowhead well is there a concentration of carbonaceous material suitable for paleontological analysis. The upper surface of unit $P_{2}$ locally shows signs of desiccation and neomineralization in the form of pyrite-filled cracks localized in the upper foot of the kaolin.

Unit $\mathrm{P}_{2}$ is barely fossiliferous and preservation of microflora is poor. The sample from the Arrowhead well contains the dinoflagellates Eocladopyxis peniculata Morgenroth and Lentinia sp. The former species ranges in age from late Paleocene to Eocene, but the position of unit $P_{2}$ relative to unit $E_{1}$ and the lithologic similarity of $\mathrm{P}_{2}$ with known Paleocene formations strongly suggest that its age is late Paleocene. The presence of marine misrofossils indicates that unit $P_{2}$ was deposited in or near a marine environment, but the uniformity $\varepsilon$ nd postdeposition alteration of the unit makes it difficult to establish the depositional environment. This unit could have been laid down in a large delta complex during late Paleocene time, or it could be an open-marine shelf deposit with post-depositional processes removing the characteristic marine constituerts.

The biostratigraphic equivalents of $u^{n i t} \mathrm{P}_{2}$ in western Georgia are the Nanafalia Formation and the Baker Hill Formation of Gibson (1982). In western South Carolina, the biostratigraphic equivalent of unit $\mathrm{P}_{2}$ is probably the upper Paleocene Black Mingo Formation, whereas in eastern South Caroline it is the upper part of the Black Mingo Group of Van Nieuwenhuise and Colquhoun (1982).

\section{Unit $\mathbf{P}_{1}$}

This unit is a poorly consolidated clayey sand grading vertically to a laminated silty clay. The basal contact is marked by a coarse, angular quartz sand containing a small percentage of kaolin mat-ix. The sediment overlying this basal sand is general $\%$ fine to medium, poorly sorted, angular quartz sand and silt. Matrix kaolin reaches a maximum of 30 percent of the bulk sample. The sand is typically smoky quartz, which combines with the off-white to pale-grey clay to 
give unit $P_{1}$ a characteristic light-gray appearance. Mica, dark heavy minerals, clay clasts, and lignite fragments are also common in the sandier parts of this unit. The upper half of unit $P_{1}$ is characteristically very clayey and very carbonaceous as compared to the lower half of the unit. The upper clayey sequence is composed of thinly laminated silty clay and very micaceous clay. Medium - to dark-gray layers of thinly bedded, highly carbonaceous clay are indicative of the upper part of unit $P_{1}$. In eastern Georgia and South Carolina, the upper part of $\mathrm{P}_{1}$ contains beds of sandy clay, which contain significant amounts of cristobalite. The cristobalite, in conjunction with the kaolin matrix, causes the beds to be moderately indurated and colors them pale green. The tops of clay-rich beds may show red staining, probably from the oxidation of iron-bearing heavy minerals during a hiatus in deposition.

Samples of the gray clays from cores in unit $\mathrm{P}_{1}$ contain diagnostic assemblages of pollen, dinoflagellates, and calcareous nannofossils. Calcareous nannofossils from the middle of unit $P_{1}$ include Chiasmolithus consuetus (Bramlette \& Sullivan) Hay et al., Cruciplacolithus tenuis (Stradner) Hay \& Mohler, and Neochiastozygus concinnus (Martini) Perch-Nelson, which are characteristic of Zone NP 3. Dinoflagellates from this unit are poorly preserved but include Cordosphaeridium fibrospinosum Davey \& Williams, Deflandrea sp. cf. $D$. diebelii of Drugg (1967), Peridiniacean cyst sp. B of Edwards (1980), Senegalinium obscurum (Drugg) Stover \& Evitt, Palaeoperidinium pyrophorum (Ehrenberg) Sarjeant, and Spinidinium densispinatum Stanley. In addition, samples from the base of unit $P_{1}$ in the western wells contain Danea californica (Drugg) Stover \& Evitt, and samples from the top of $\mathrm{P}_{1}$ contain Andalusiella sp. aff. A. polymorpha of Edwards (1980), Fibradinium annetorpense Morgenroth, Fibrocysta bipolaris (Cookson \& Eisenack) Stover \& Evitt, Hafniasphaera septata (Cookson \& Eisenack) Hansen, and Peridiniacean cyst sp. C of Edwards (1980). All of these microflora are indicative of a Paleocene (Midwayan) age. The well-developed marine flora in unit $\mathrm{P}_{1}$ and the high percentage of organic debris suggest that the unit was deposited in a restricted to open-marine environment, perhaps along the margin of a large delta. The sand at the base of the unit may represent the delta-front deposits, whereas the clays in the top of the unit may be bay and channel fills or back-barrier lagoon deposits.

In some wells (for example, the Arrowhead well), unit $P_{1}$ can be easily subdivided into a sand unit and an overlying clay unit; however, they are considered together in this report because this separation is not always possible (for example, Laurens 1). Biostratigraphically, the sand in the lower part of $\mathrm{P}_{1}$ in the Arrowhead well is equivalent to the Clayton Formation of western Georgia, and the clay in the upper part of $P_{1}$ is equivalent to the Porters Creek Formation (table 2). The lower part of $\mathrm{P}_{1}$ contains a considerable amount of sand, as does the updip Clayton Formation (Reinhardt and Gibson, 1980), but openmarine indicators such as glauconite and megafossils, which characterize the Clayton, are not present in $P_{1}$. Similarly, only the black, finely laminated clays in the upper part of $P_{1}$ resemble the Porters Creek lithology of western Georgia. The white kaolinitic clays in the upper part of $\mathrm{P}_{1}$ resemble the lower part of the Huber Formation of Buie (1978). However, sediments of the Ellenton Formation of Siple (1967) more closely match the lithology of unit $\mathrm{P}_{1}$ and also are biostratigraphically equivalent (Faye and Prowell, 1982).

\section{Unit $\mathbf{U K}_{6}$}

This unit is a silty clay to very clayey sand containing thin beds of clayey coarse sand and gravel. The sand is predominantly fine to medium, subangular, clear or smoky quartz, which is mocerately sorted. Mica, minor feldspar, garnet, and other dark heavy minerals are present as accessory minerals. This sand characterizes the basal part of unit $U K_{6}$ and is also interbedded with the clays in the upper part of the unit. In the upper part, white to buff kaolin constitutes as much as 40 percent of the sandier beds and as much as 80 percent of the silty clay beds. Very clayey beds are typically micaceous, ar $f$ some contain thin, medium- to dark-gray carbonaceous intervals. Carbonaceous debris also is present in the sandier beds but generally in the form of lignitic fragments. The top of unit $\mathrm{UK}_{6}$ characteristically contains an orangered oxidized zone 20 to $40 \mathrm{ft}$ thick. This zone probably reflects post- $\mathrm{UK}_{6}$ and pre-Paleocene weathering of the top of the Cretaceous strata.

Samples of pollen from the carbonaceous clay layers in this unit contain a variety of palynomorphs including Ruqubivesiculites sp., Pseudctlantopollis $\mathrm{cf}$. $P$. simulatus, and Momipites sp. (NK 3) that are representative of Upper Cretaceous (middle Maestrichtian) strata elsewhere (Christopher, 1978; Sohl and Christopher, 1983). This age designation makes unit $\mathrm{UK}_{6}$ the youngest Cretaceous unit in the updip Coastal Plain of central Georgia. Dinoflagellates and acritarchs are present in most of the $\mathrm{UK}_{6}$ pollen samples, but they are plentiful only in the lower parts of the unit (sandy phas?). The sorting of the sand and the abundant marine microflora suggest the lower sandy beds formed in an open-marine environment. The scarcity of marine indicators and the very clayey, carbonaceous, well-siorted nature of the clayey upper part of this unit suggest that it probably is part of a restricted-marine delta plain.

The Providence Sand of western Georgia and parts of the Peedee Formation of Snuth and North Carolina are the biostratigraphic equivalents of unit $\mathrm{UK}_{6}$. None of these units are lithostratigraphic equivalents, but it is likely that the clayey silt and sand of $\mathrm{UK}_{6}$ represent the more continental facies of the Providence Sand.

\section{Unit $\mathbf{U K}_{\mathbf{5}}$}

This unit is predominantly a well-sorted, fine to medium, subrounded quartz sand and silt containing minor amounts of fine mica, feldspar, and dark heavy minerals. Off-white to buff kaolin forms a matrix for the sand east of the Laurens-1 well, whereas the clay in the Laurens and Pulaski wells is medium to dark green and probably montmorillonitic. Samples from these wells also contain shell fragments in small quantities. The sand at the base of the unit typically contains more clay in the matrix, whereas the top of the unit is generally finer and may or may not contain clay. Thin beds of micaceous, highl: carbonaceous clay are present throughout the unit, and lignitized wood is present in many samples of this clay.

Pollen samples taken from the carbonaceous 
clays in unit $\mathrm{UK}_{5}$ contain a diverse assemblage. The microflora includes Rugubivesiculites sp., Triatriopollenites sp. B (NP 2), Betulaceoipollenites sp. A (NO-3), and aff. Plicapollis sp. A (NN-1), which are indicative of Late Cretaceous (early Maestrichtian) age elsewhere (Christopher, 1978; Sohl and Christopher, 1983). All of the samples contain an abundance of dinoflagellates and acritarchs, suggesting an open-marine environment. The subrounded, wellsorted nature of the sand and the microfossil evidence suggest that unit $\mathrm{UK}_{5}$ is part of a back-barrier and barrier-bar complex.

The biostratigraphic equivalents of unit $\mathrm{UK}_{5}$ are the Ripley and upper Cusseta Formations in western Georgia (Sohl and Smith, 1980), the Black Creek Formation of South Carolina, and the lower part of the Peedee Formation in North Carolina (Christopher, 1978; Sohl and Christopher, 1983). In many ways, the sands of unit $\mathrm{UK}_{5}$ lithologically resemble the crossbedded sand in the Ripley Formation described by Reinhardt and Gibson (1980). Similarly, unit $\mathrm{UK}_{5}$ also resembles some lithofacies of the Black Creek Formation, but does not contain the abundant carbonaceous debris characteristic of the Black Creek.

\section{Unit $\mathbf{U K}_{\mathbf{4}}$}

Unit $\mathrm{UK}_{4}$ is divided into two subunits, $\mathrm{UK}_{4 \mathrm{a}}$ and $\mathrm{UK}_{4 \mathrm{~b}}$, to describe a facies change that occurs between the Arrowhead and Laurens test wells. The upper part of $\mathrm{UK}_{4 \mathrm{~b}}$ in the Laurens-1 and -3 wells may contain some of the UK 4 a lithofacies, but no core was recovered from this interval.

Subunit $\mathrm{UK}_{4 \mathrm{a}}$ is a gray-to-green clayey silt to fine sand that is very micaceous, very carbonaceous, and locally glauconitic. The base of the subunit is marked by a slightly clayey, fine to coarse quartz sand about $25 \mathrm{ft}$ thick, whereas the overlying strata are thinly laminated and some intervals are burrowed. Parts of $\mathrm{UK}_{4}$ contain shells of bivalves and other macrofossils, but they typically are not confined to discrete beds. The fossiliferous part of the subunit contains some thin limestone beds and calcareous cement in the clays. Dark heavy minerals are present, but they have not been identified individually.

Subunit $\mathrm{UK}_{4 \mathrm{~b}}$ is a clayey quartz sand to silty clay containing thick carbonaceous clay beds. The sand is generally fine to medium, subangular to subrounded quartz and is typically light gray. Dark heavy minerals and minor amounts of feldspar, mica, and nodular pyrite are also present. Clay-rich layers contain minor amounts of silt and sand and are thinly laminated. Some of the laminae contain abundant mica and fine-grained heavy minerals. Beds of soft, coarsely crystalline kaolin are characteristic of the top of unit $\mathrm{UK}_{4 \mathrm{~b}}$ and are of commercial purity in many instances.

Pollen samples collected from the carbonaceous clays in unit $\mathrm{UK}_{4}$ contain Rugubivesiculites sp., Plicapollis sp. B (NN-1), Holkopollenites sp. (CP3E-1), Casuarinidites cf. C. granilabratus (NO-2), Choanopollenites sp. B (NA-7), and Osculapollis aequalis (NO-1). These fossils indicate a Late Cretaceous (late Campanian to earliest Maestrichtian(?)) age (Christopher, 1978; Sohl and Christopher, 1983). Samples from the Arrowhead and Laurens -1 and -3 test wells contain an abundance of dinoflagellates and acritarchs suggestive of an openmarine source. An open-marine environment would similarly explain the numerous bivalve she'ls in the Arrowhead samples. Marine macrofossils are absent in unit $\mathrm{UK}_{4}$ east of the Arrowhead test well, and marine microfossils are much less abundant east of the Laurens test wells. The decline in the number of marine organisms from west to east suggest: that the environment of deposition becomes marginal marine to restricted marine in eastern Georgia and South Carolina. The thinly laminated sand, silt, and clay of subunit $\mathrm{UK}_{4 \mathrm{~b}}$ and its highly carbonaceous c!'rys most likely reflect a delta-plain environment subjected to active marine influence. The massive, glauccnitic, and fossiliferous nature of subunit $\mathrm{UK}_{4 \mathrm{a}}$, however, probably reflects a delta-front or prodelta environment.

Unit $\mathrm{UK}_{4}$ is the biostratigraphic equivalent of the lower part of the Cusseta Formation of western Georgia and parts of the Black Creek Formation of South and North Carolina (table 2). Subunit $\mathrm{UK}_{4}$ resembles some lithofacies of the Cusreta, but otherwise could not be lithologically equated with the formation. The black laminated parts of subunit $\mathrm{UK}_{4 \mathrm{p}}$, however, are very similar to the outcropping Black Creek Formation of the Carolinas, and a lithologic correlation with that unit is reasonable.

\section{Unit $\mathbf{U K}_{\mathbf{3}}$}

This unit exists only in the Arrowhead and Laurens-3 test wells and consists of a basal clayey sand to silt overlain by thick alternating beris of silty clay and medium to coarse sand. The silty clays in the basal part of the unit are highly carbonaceous and contain abundant mica. In the Arrowhead test well, a section consisting of well-defined cyclic alternations of sand and clay overlies this basal section. Three complete sand-clay cycles are present in the Arrowhead well, and perhaps one is present in the top of unit $\mathrm{UK}_{3}$ in the Laurens-3 well. The sand layer in a typical cycle generally consists of medium to coarse, moderately sorted, subangular quartz with only a minor amount of clay as a matrix. Tl a quartz typically is clear or light gray, and accessory minerals include feldspar, mica, and dark heavy mine"als. The clay layer in a typical cycle is largely clayey silt to silty clay with minor amounts of sand dispersed throughout the layer. Sandier intervals within the clay layer characteristically contain abundant mira. Some intervals within the clay layers ar? highly carbonaceous, but typically the tops of the clay layers are stained red by iron oxidation, possibly due to subaerial weathering.

Pollen samples collected from the carbonaceous clay layers contain a diverse suite of palynomorphs including Rugubivesiculites sp., Comp'oxiopollis abditus (NB-1), Holkopollenites sp. A (CP3 D-1), Proteacidites sp. B (PR-1), and Trudopollis sp. A (NF1), which indicate a Late Cretaceous (early to middle Campanian) age (Christopher, 1978; Sohl and Christopher, 1983). Dinoflagellates and acritarchs are present in all of the samples, but the quentity and diversity of forms is very limited. The sand-clay cycles and the marine microfossils suggest that unit $\mathrm{UK}_{3}$ was probably part of a delta-plain or nearshore estuarine environment similar to the depositional environment of unit $\mathrm{UK}_{2}$. Unit $\mathrm{UK}_{3}$, howe"er, lacks many of the high-energy characteristics typical of unit $\mathrm{UK}_{2}$.

The Blufftown Formation of western Georgia is 
the biostratigraphic equivalent of unit $\mathrm{UK}_{3}$, but it is not the lithostratigraphic equivalent. The Blufftown, according to Reinhardt and Gibson (1980), contains a significant amount of glauconite, calcareous clay, and other open-marine indicators. Strata of similar age have not been reported from the outcropping Cretaceous in South Carolina, but Christopher (1978) identified a similar microflora in the Clubhouse Crossroads corehole near Charleston, S.C., and along the Cape Fear River in North Carolina (Sohl and Christopher, 1983). Gohn and others (1977) described the South Carolina sediments as gray to grayish-green, calcareous, fossiliferous silty clay and muddy sand, and placed them in the lower part of the Black Creek Formation. Hence, it appears that unit $\mathrm{UK}_{3}$ is confined to the subsurface of central and eastern Georgia.

\section{Unit $\mathbf{U K}_{2}$}

This unit is a poorly consolidated clayey sand composed of fine to very coarse, angular to subangular quartz sand, silt, and some smoky-quartz gravel in a matrix of soft, white to buff kaolin. The quartz sand is generally clear to white, or, less commonly, gray to light red, whereas the quartz gravel is predominantly light to dark gray. Minor amounts of feldspar, sparse to abundant mica, staurolite, garnet, pyrite, monazite, and unidentified heavy minerals are also present. Kaolin balls and lignite fragments are present in the sandier beds. Bed thickness and grain size are highly variable, and inclined bedding suggests the presence of crossbedding. Fining-upward cycles consisting of coarse sands that grade upward into clay-and-silt layers are common, and a zone of iron oxidation and red staining typically exists at the top of the clay and silt beds.

Pollen samples from unit $\mathrm{UK}_{2}$ yield moderate numbers of palynomorphs including Rugubivesiculites sp., Porocolpopollenites sp. (CP-3b), Minorpollis sp. B, Complexiopollis $\mathrm{sp} . \mathrm{B}$, and Complexiopollis $\mathrm{sp} . \mathrm{D}$, which characterize Pollen Zone $\mathrm{V}$ and indicate a Late Cretaceous (Santonian) age (Christopher, 1982). The occurrence of dinoflagellates and acritarchs in the pollen-bearing clays indicates a definite marine influence during deposition, but the relatively low percentage of marine microfossils per sample suggests that marine influence was restricted. The variability of grain size, evidence of crossbedding and finingupward cycles, and marine microflora suggest that unit $\mathrm{UK}_{2}$ was deposited in a lower delta plain or in a proximal marine environment.

Christopher and others (1979) report that a similar microflora exists in the Middendor $f$ Formation of South and North Carolina and in the Eutaw Formation of western Georgia. In regard to environment of deposition and lithology, unit $\mathrm{UK}_{2}$ closely resembles the Middendorf Formation of the Carolinas. In eastern Georgia, unit $\mathrm{UK}_{2}$ can be distinguished from unit $\mathrm{UK}_{1}$ by its lack of cristobalite, lack of induration, and increased amount of carbonaceous debris.

\section{Unit UK 1}

This unit is a dense clayey sand composed of poorly sorted, fine to very coarse, angular quartz sand and some smoky-quartz gravel in a matrix of buff to pale-green cristobalitic kaolin. A 1 - to 2-foot-thick bed of very coarse quartz gravel mark? the basal unconformity, regardless of underlying roc's type. The sand fraction in this unit is largely quartz in a variety of colors (pink-to-red, white, gray, and clear), but it also contains minor amounts of potassium feldspar, mica, and a variety of heavy minerals including garnet, staurolite, and monazite. The clay forming the matrix and individual clay beds is mostly ksolinite with minor montmorillonite. Alternating beds of different grain size are present in fining-upward cycles, suggesting considerable variation in energy of deposition. Carbonaceous clays are rare, but lignite fragments are more common. Much of the primary carbon may have been destroyed by oxidation. Paleorange and red staining in many of the comes suggests that the strata have experienced periodic weathering and oxidation. The abundance of cristob lite in the matrix gives unit $\mathrm{UK}_{1}$ its distinct internal cohesion, resulting in characteristically low resistivity on electric logs. The abundance of cristobalite cannot be attributed to local rock terranes and siggests the influence of distant felsic volcanic activity.

Pollen samples from thin carbonaceous clay layers yield a low diversity of palynomonphs, which include Rugubivesiculites sp., Porocolpopollenites sp. (CP-3b), Complexiopollis sp. B, and Complexiopollis sp. $D$ (Christopher and others, 1979). These palynomorphs are indicative of Pollen Zone V of Late Cretaceous (Santonian) age. Dinoflagellates are rare in these samples, which suggests a distal marine inf'rence. The variability in grain size, the abundance of cristobalite, and the sparse marine flora suggest that unit $U_{1}$ was deposited in an upper-delta-plain environment.

Christopher and others (1979) report that a similar microflora exists in the Cape Fear Formation of North and South Carolina and the Eutav' Formation of western Georgia (table 2). Lithologically, however, unit $\mathrm{UK}_{1}$ closely resembles the Cape Fear Formation.

\section{Unit R}

This unit consists of a laterally extensive group of highly oxidized red beds that are charesterized by very indurated claystones, siltstones, sandstones, and fanglomerates. Lithologic descriptions from nearby petroleum test wells (for example, Dana 1; Milton and Hurst, 1965, p. 43) indicate that simiar red-bed sequences are thousands of feet thick. There rocks are stratigraphically and lithologically equivalent to the Triassic and Jurassic continental red beds exposed in North Carolina, South Carolina, and Virginia, and to similar rocks in the subsurface of the $A$ tlantic and Gulf Coastal Plains.

\section{Unit Pz}

This unit consists of saprolite of phyllite at the upper greenschist facies of regional metamorphism and is present only in the Laurens-3 test well. Most of these rocks are probably derived from vclcaniclastic materials of felsic to intermediate composition. They closely resemble metavolcanic phyllites exrosed in the southern Piedmont of Georgia and South Carolina, where they have been dated by megafossil evidence as early Paleozoic (probably Cambrian) (Maher and others, 1981). Similar rock types have been reported in other Coastal Plain drill holes in nearby areas by Applin (1951) and Milton and Hurst (1965). 


\section{REFERENCES CITED}

Applin, P.L., 1951, Preliminary report on buried preMesozoic rocks in Florida and adjacent States: U.S. Geological Survey Circular 91, 28 p.

Bechtel Corporation, 1982, Studies of postulated Millett fault, prepared for Georgia Power Company Vogtle Nuclear Plant: Unpublished report, v. 1 and v. 2, variously paged.

Buie, B.F., 1978, The Huber Formation of easterncentral Georgia, in Short contributions to the geology of Georgia: Georgia Geologic Survey Bulletin 93, p. 1-7.

Bybell, L.M., and Gibson, T.G., 1985, The Eocene Tallahatta Formation of Alabama and Georgia-its lithostratigraphy, biostratigraphy, and bearing on the age of the Claibornian Stage: U.S. Geological Survey Bulletin 1615, 20 p., 2 pl.

Christopher, R.A., 1978, Quantitative palynologic correlation of three Campanian and Maestrichtian sections (Upper Cretaceous) from the Atlantic Coastal Plain: Palynology, v. 2, p. 1-27.

1982, Palynostratigraphy of the basal Cretaceous units of the eastern Gulf and southern Atlantic Coastal Plains, in Arden, D.D., Beck, B.F., and Morrow, Eleanore, eds., Proceedings, Second symposium on the geology of the Southeastern Coastal Plain: Georgia Geologic Survey Information Circular 53, p. 10-23.

Christopher, R.A., Owens, J.P., and Sohl, N.F., 1979, Late Cretaceous palynomorphs from the Cape Fear Formation of North Carolina: Southeastern Geology, v. 20, no. 3, p. 145-159.

Drugg, W.S., 1967, Palynology of the upper Moreno Formation (Late Cretaceous-Paleocene), Escarpedo Canyon, California: Palaeontographica, Abt. B, v. 120 , p. 1-71.

Drugg, W.S., and Stover, L.E., 1975, Stratigraphic range charts of selected Cenozoic dinoflagellates, in Evitt, W.R., ed., Proceedings of a forum on dinoflagellates: American Association of Stratigraphic Palynologists Contributions series, no. 4, p. 73-76.

Edwards, L.E., 1980, Dinoflagellate biostratigraphy -a first look, in Reinhardt, Juergen, and Gibson, T.G., Upper Cretaceous and lower Tertiary geology of the Chattahoochee River Valley, western Georgia and eastern Alabama, in Frey, R.W., ed., Excursions in Southeastern geology: Geological Society of America Field Trip Guidebook, 1980 Annual Meeting, v. 2, p. 424427.

Faye, R.E., and Prowell, D.C., 1982, Effects of Late Cretaceous and Cenozoic faulting on the geology and hydrology of the Coastal Plain near the Savannah River, Georgia and South Carolina: U.S. Geological Survey Open-File Report 82-156, 75 p., 8 oversize sheets.

Gibson, T.G., 1982, New stratigraphic unit in the Wilcox Group (upper Paleocene-lower Eocene) in Alabama and Georgia, in Stratigraphic notes, 1980-1982--Contributions to Stratigraphy: U.S. Geological Survey Bulletin 1529-H, p. H23-H32.

Gohn, G.S., Higgins, B.B., Smith, C.C., and Owens, J.P., 1977, Lithostratigraphy of the deep corehole (Clubhouse Crossroads corehole 1) near Charleston, South Carolina, in Rankin, D.W., ed., Studies related to the Charleston, South
Carolina, earthquake of $1886-\mathrm{a}$ preliminary report: U.S. Geological Survey F'ofessional Paper 1028, p. 59-70.

Hazel, J.E., Bybell, L.M., Christopl or, R.A., Frederiksen, N.O., May, F.E., McLean, D.M., Poore, R.Z., Smith, C.C., Sohl, N.F., Valentine, P.C., and Witmer, R.J., 1977, Biostratigraphy of the deep corehole (Clubhouse Crossroads corehole 1) near Charleston, South Carolina, in Rankin, D.W., ed., Studies related to the Charleston, South Carolina earthquake of $1886-\mathrm{a}$ preliminary report: U.S. Geological Survey Professional Paper 1028, p. 71-89.

Hazel, J.E., Edwards, L.E., and Bybell, L.M., 1984, Significant unconformities and the hiatuses represented by them in the Paleog sne of the Atlantic and Gulf Coastal Province, in Schlee, J.S., ed., Interregional unconformities and hydrocarbon accumulation: American Association of Petroleum Geologists Memoir 36, p. 59-66.

Huddlestun, P.F., and Hetrick, J.H., 1979, The stratigraphy of the Barnwell Group of Georgia: Georgia Geologic Survey Open-File Report 80-1, 89 p.

Maher, H.D., Palmer, A.R., Secor, D.T., Jr., and Snoke, A.W., 1981, New trilobite locality in the Piedmont of South Carolina, and its regional implications: Geology, v. 9, no. 1, p. 34-36.

Marine, I.W., and Siple, G.E., 1974, Buried Triassic basin in the central Savannah River area, South Carolina and Georgia: Geological Society of America Bulletin, v. 85 , no. 2, p. $311-i 20$.

Martini, Erland, 1971, Standard Tertiary and Quaternary calcareous nannoplanktor zonation, in Farinacci, Anna, ed., Proceedinrs of the Second Planktonic Conference Roma 1970, Rome, Edizioni Tecnoscienza, p. 739-785.

Milton, Charles, and Hurst, V.J., 1965, Subsurface "basement" rocks of Georgia: Georgia Geological Survey Bulletin 76, 56 p.

Nystrom, P.G., Jr., and Willoughby, R.H., 1982, Geological investigations related to the stratigraphy in the kaolin mining district, Aiken County, South Carolina: Carolina Geological Society Field Trip Guidebook 1982, $18 \hat{i}$ p.

Pooser, W.K., 1965, Biostratigraphy of Cenozoic ostracoda from South Carolina: University of Kansas Paleontological Contribution-, no. 38, Arthropoda, Art. 8, 80 p.

Prowell, D.C., and $O^{\prime}$ Connor, B.J., 1978, Folair fault zone--evidence of Tertiary fault displacement in eastern Georgia: Geology, v. 6, no. 10, p. 681684.

Reinhardt, Juergen, and Gibson, T.G., 1؟90, Upper Cretaceous and lower Tertiary geolngy of the Chattahoochee River Valley, western Georgia and eastern Alabama, in Frey, R.W., ed., Excursions in Southeastern geology: Geological Society of America Field Trip Guidehook, 1980 Annual Meeting, v. 2, p. 385-463.

Siple, G.E., 1967, Geology and ground water of the Savannah River Plant and vicinity, South Carolina: U.S. Geological Survey Water-Supply Paper 1841, 113 p.

Sohl, N.F., and Christopher, R.A., 1983, The Black Creek-Peedee formational contact (Upper Cretaceous) in the Cape Fear River region of North Carolina: U.S. Geologic 1 Survey 
Professional Paper 1285, 37 p.

Sohl, N.F., and Smith, C.C., 1980, Notes on Cretaceous biostratigraphy, in Reinhardt, Juergen, and Gibson, T.G., 1980, Upper Cretaceous and lower Tertiary geology of the Chattahoochee River Valley, western Georgia and eastern Alabama, in Frye, R.W., ed., Excursions in Southeastern geology: Geological Society of America Field Trip Guidebook, 1980 Annual Meeting, v. 2, p. 392-402.

Van Nieuwenhuise, D.S., and Colquhoun, D.J., 1982, The Paleocene-lower Eocene Black Mingo Group of the east-central Coastal Plain of South Carolina: South Carolina Geology, v. 26, no. 2, p. 47-67.
Ward, L.W., Blackwelder, B.W., Gohn, G.S., हnd Poore, R.Z, 1979, Stratigraphic revision of Eocene, Oligocene, and lower Miocene formations of South Carolina: South Carolina Geological Survey, Geologic Notes, v. 23, no. 1, p. 2-32.

Williams, G.L., and Brideaux, W.W., 1975, Palynological analyses of Upper Mesozoic and Cenozoic rocks of the Grand Banks, Atlantic continental margin: Geological Survey of Canada Bulletin 236, 162 p.

Wolfe, J.A., 1976, Stratigraphic distributior of some pollen types from the Campanian and lower Maestrichtian rocks (Upper Cretaceol's) of the Middle Atlantic States: U.S. Geological Survey Professional Paper 977, 18 p. 